\title{
Residual hemothorax after chest tube placement correlates with increased risk of empyema following traumatic injury
}

\author{
Riyad Karmy-Jones $M D^{1}$, Michele Holevar $\mathrm{MD}^{2}$, Ryan J Sullivan $\mathrm{MD}^{2}$, Ani Fleisig $M D^{1}$, Gregory J Jurkovich $\mathrm{MD}^{1}$
}

R Karmy-Jones, M Holevar, RJ Sullivan, A Fleisig, GJ Jurkovich. Residual hemothorax after chest tube placement correlates with increased risk of empyema following traumatic injury. Can Respir J 2008;15(5):255-258.

BACKGROUND: Empyema complicates tube thoracostomy following trauma in up to $10 \%$ of cases. Studies of potential risk factors of empyema have included use of antibiotics, site of injury and technique of chest tube placement. Residual fluid has also been cited as a risk factor for empyema, although the imaging technique to identify this varies.

OBJECTIVE: To determine whether residual hemothorax detected by chest $\mathrm{x}$-ray (CXR) after one or more initial chest tubes predicts an increased risk of empyema.

METHODS: A study of patients admitted to two level I trauma centres between January 7, 2004, and December 31, 2004, was conducted. All patients who received a chest tube in the emergency department, did not undergo thoracotomy within $24 \mathrm{~h}$, and survived more than two days were followed. Empyema was defined as a pleural effusion with positive cultures, and a ratio of pleural fluid lactate dehydrogenase to serum lactate dehydrogenase greater than 0.6 in the setting of elevated leukocyte count and fever. Factors analyzed included the presence of retained hemothorax on CXR after the most recent tube placement in the emergency room, age, mechanism of injury and injury severity score.

RESULTS: A total of 102 patients met the criteria. Nine patients (9\%) developed empyema: seven of 21 patients (33\%) with residual hemothorax developed empyema versus two of 81 patients $(2 \%)$ without residual hemothorax developed empyema $(\mathrm{P}=0.001)$. Injury severity score was significantly higher in those who developed empyema $(31.4 \pm 26)$ versus those who did not $(22.6 \pm 13 ; \mathrm{P}=0.03)$. CONCLUSIONS: The presence of residual hemothorax detected by CXR after tube thoracostomy should prompt further efforts, including thoracoscopy, to drain it. With increasing injury severity, there may be increased benefit in terms of reducing empyema with this approach.

Key Words: Empyema; Residual hemothorax; Tube thoracostomy

$\mathrm{T}$ ube thoracostomy plays a fundamental role in the management of chest trauma. Primarily, in the acute setting, this procedure is used to drain pneumothorax and treat massive hemothorax. It is often considered a relatively minor procedure, but can be associated with significant complications, including misplacement, laceration of organs, pain and infection (eg, empyema). In the trauma setting, empyema can be roughly divided into two groups: those occurring as a

\author{
Un hémothorax résiduel après l'installation \\ d'un drain thoracique est lié à une \\ augmentation du risque d'empyème après un \\ traumatisme
}

HISTORIQUE : L'empyème complique la thoracostomie par drain dans près de $10 \%$ des cas après un traumatisme. Les études des facteurs de risque potentiels d'empyème ont porté sur l'utilisation d'antibiotiques, le foyer du traumatisme et la technique d'installation du drain thoracique. La présence de liquide résiduel est également citée comme un facteur de risque d'empyème, même si la technique d'imagerie utilisée pour la dépister varie.

OBJECTIF : Déterminer si un hémothorax résiduel décelé par radiographie thoracique (RGT) après un ou plusieurs drains thoraciques initiaux est prédicteur d'une augmentation du risque d'empyème.

MÉTHODOLOGIE : Les auteurs ont mené une étude auprès de patients hospitalisés dans deux centres de traumatologie de niveau I entre le 7 janvier et le 31 décembre 2004. Aucun des patients qui avaient reçu un drain thoracique à l'urgence n'avait subi de thoracotomie dans les 24 heures. Les patients qui ont survécu plus de deux jours ont fait l'objet d'un suivi. L'empyème était défini comme une effusion pleurale accompagnée de cultures positives et par un ratio entre la lacticodéshydrogénase du liquide pleural et la lacticodéshydrogénase sérique supérieur à 0,6 en présence de leucocytémie élevée et de fièvre. Les facteurs analysés étaient le maintien de l'hémothorax à la RGT après l'installation du drain thoracique le plus récent à l'urgence, l'âge, le mécanisme du traumatisme et son indice de gravité.

RÉSULTATS : Au total, 102 patients respectaient les critères. Neuf patients (9\%) ont souffert d'empyème, soit sept des 21 patients (33\%) présentant un hémothorax résiduel par rapport à deux des 81 patients ( $2 \%)$ n'en présentant pas $(\mathrm{P}=0,001)$. L'indice de gravité du traumatisme était considérablement plus élevé chez les patients qui souffraient d'empyème $(31,4 \pm 26)$ que chez ceux qui n'en souffraient pas $(22,6 \pm 13$; $\mathrm{P}=0,03)$.

CONCLUSIONS : La présence d'un hémothorax résiduel décelé par RGT après une thoracostomie par drain devrait susciter des efforts supplémentaires, y compris une thoracoscopie, afin de bien le drainer. Avec la gravité croissante du traumatisme, cette démarche pourrait comporter des bienfaits supplémentaires à l'égard de la réduction de l'empyème.

${ }^{1}$ Department of Surgery, Harborview Medical Center, Seattle, Washington; ${ }^{2}$ Department of Surgery, Mount Sinai Hospital, Chicago, Illinois, USA Correspondence: Dr Riyad Karmy-Jones, Thoracic and Vascular Surgery, Southwest Washington Medical Center, Division of Cardiothoracic

Surgery, Harborview Medical Center, University of Washington, SWMC, Physicians' Pavilion, Suite 300, 200 North East Mother Joseph

Place, Vancouver, Washington 98664, USA. Telephone 360-514-1854, e-mail rkarmyjo@swmedicalcenter.com 
TABLE 1

\section{Patient characteristics}

\begin{tabular}{lccc}
\hline & \multicolumn{3}{c}{ Mechanism of injury, n (\%) } \\
\cline { 2 - 4 } & $\begin{array}{c}\text { Blunt } \\
(\mathbf{n}=\mathbf{7 7})\end{array}$ & $\begin{array}{c}\text { Gunshot } \\
\mathbf{( n = 1 0 )}\end{array}$ & $\begin{array}{c}\text { Stab wound } \\
\mathbf{( n = 1 5 )}\end{array}$ \\
\hline $\begin{array}{l}\text { Mortality } \\
\text { Diaphragmatic injury }\end{array}$ & $7(9)$ & $1(10)$ & $1(7)$ \\
$\begin{array}{l}\text { Procedure } \\
\quad \text { Laparotomy within 24 } \mathrm{h}\end{array}$ & $15(19)$ & $0(0)$ & $8(33)$ \\
$\quad \begin{array}{l}\text { Intubation within 24 } \mathrm{h} \text { for } \\
\quad 10(13)\end{array}$ & $4(40)$ & $5(33)$ \\
$\quad$ acute lung injury & & & $0(0)$ \\
$\quad$ Multiple tubes & $2(3)$ & $3(30)$ & $1(7)$ \\
Right-sided hemothorax & $49(64)$ & $2(20)$ & $3(20)$ \\
Residual hemothorax & $11(14)$ & $2(20)$ & $8(53)$ \\
Empyema & $4(5)$ & $0(0)$ & $5(33)$ \\
\hline
\end{tabular}

their use. However, the general consensus is that a sterile technique and as complete an evacuation of the hemothorax as possible are necessary for prevention. It has been shown that chest computed tomography (CT) scans or ultrasound (US) are more accurate than plain chest $\mathrm{x}$-ray (CXR) in detecting the presence and true volume of residual pleural fluid in the acute setting (7-9). In addition, depending on the clinical circumstances, effusions detected by CT but not by plain radiograph may not need drainage (10). We wished to determine whether routine CXR might have a predictive ability to identify patients at risk of developing empyema after tube thoracostomy.

\section{METHODS}

Patients admitted to Harborview Medical Center (Washington, USA) and Mount Sinai Hospital (Illinois, USA) between January 7, 2004, and December 31, 2004, who underwent tube thoracostomy in the emergency department were followed. Patients were excluded if they underwent thoracotomy or thoracoscopy within $24 \mathrm{~h}$, or died within $48 \mathrm{~h}$. In addition, patients who received bilateral tubes were excluded. Data collected included age, sex, mechanism of injury, site of injury, systolic blood pressure on arrival, injury severity score (ISS), chest abbreviated injury score, injuries, need for laparotomy, presence of acute lung injury requiring intubation, number of chest tubes placed in the emergency room, amount of blood drained in the first $24 \mathrm{~h}$, duration of antibiotics, and presence or absence of residual fluid documented on the most recent CXR before leaving the emergency room. Pre-existing comorbidities were also recorded, including diabetes, chronic obstructive pulmonary disease, steroid use and/or cardiac disease. Patients receiving bilateral tube thoracostomies were not included simply to make analysis more uniform and thus easier. The majority of CXRs following penetrating injury were upright films; the majority following blunt injury were supine films.

All patients had tube thoracostomy performed using sterile equipment, including gowns, gloves and masks. The procedure was performed by surgical residents at least at a third-year level, who had received instruction during previous trauma, critical care and thoracic rotations. All patients received at least one dose of antibiotics (cefazolin), and subsequent doses were given depending on the presence of other injuries or indications.
Empyema was defined as a pleural effusion with positive cultures, and a ratio of pleural fluid lactate dehydrogenase to serum lactate dehydrogenase greater than 0.6 in the setting of elevated leukocyte count and fever. Management of these patients and indications were directed by the admitting surgeon according to his or her practice.

Permission to perform the study was obtained from the institutional review boards at Harborview Medical Center and Mount Sinai Hospital. Results are expressed as mean \pm SD. Univariate analyses were performed using the $\chi^{2}$ test for categorical data. The independent paired $t$ test was used for continuous variables. All variables significant at a level of $\mathrm{P} \leq 0.1$ were entered into a logistic regression model to determine predictors of empyema. Statistical significance was taken to be $\mathrm{P} \leq 0.05$. ORs and CIs were used to predict the risk of empyema. All statistical analyses were performed with SPSS 14 for Windows (SPSS Inc, USA).

\section{RESULTS}

A total of 102 patients met the criteria for inclusion in the study (Table 1 ). Seventy-six patients (75\%) were male. A mean $( \pm$ SD) age of $40.1 \pm 17.3$ years, ISS $23.7 \pm 11.9$, abbreviated injury score $3.4 \pm 1.3$ and systolic blood pressure on admission $107.5 \pm 38.1 \mathrm{mmHg}$ were obtained. Chest tubes were placed within $45 \pm 30 \mathrm{~min}$ of arrival. Blood loss through chest tubes in the first $24 \mathrm{~h}$ averaged $817 \pm 823 \mathrm{~mL}$. Eight patients had more than two chest tubes placed. Ultimately, nine patients died: six due to closed head injury or anoxic brain injury, and three due to complications related to multiple organ failure. However, all patient deaths occurred after seven days following admission. Overall, nine patients (9\%) developed empyema seven to 24 days following admission: five cases had undergone thoracotomy (in all patients, decortications were performed); two cases, thoracoscopy; and two cases, image-directed drainage. Lytic therapy was not used. In five patients, the predominant organism was Staphylococcus aureus; in two patients, Streptococcus species; and in two patients, a mixture of Pseudomonas species and Haemophilus influenzae.

Of note, during this time period, 12 patients underwent thoracotomy or thoracoscopy within $24 \mathrm{~h}$ of admission purely because of retained hemothorax, and none developed empyema. These patients all had isolated penetrating chest injury.

Using univariate analysis, six factors were found to be associated with risk of empyema at the $\mathrm{P} \leq 0.1$ level. These were incorporated into a simple regression analysis, and two factors (ISS and presence of residual fluid) were found to be significant (Table 2). The presence of residual fluid was associated with a 1.25 -fold (95\% CI 1.17 to 1.35 ) increased risk of empyema. Of note, empyema developed in four of 33 patients $(12 \%)$ who were covered with antibiotics (predominantly cefazolin) directed at Gram-positive bacteria throughout the time the tube thoracostomy was in place, compared with five of 69 patients (7\%) in whom the duration of antibiotic coverage was less than $48 \mathrm{~h}(\mathrm{P}=0.4)$. It should be stressed that, depending on the treating surgeon's preferences, antibiotic coverage varied. Of the four cases in which $S$ aureus was the predominant bacterial culture, one was methicillin-resistant. Of the two cases in which Streptococcus species were cultured, one was penicillin-resistant.

The two patients who developed empyema and who did not have residual fluid initially were both blunt trauma patients who had sustained a significant pulmonary contusion 
requiring intubation on admission, had prolonged ventilator courses and had developed ventilator-associated pneumonia. Their empyemas presented on hospital days 21 and 24, respectively. The bacteriology in both cases were a mixture of Pseudomonas species and $H$ influenzae, and it was assumed that these represented seeding of the hemothorax as a complication of ventilator-associated pneumonia rather than contamination at the time of tube placement. Stab wounds had a relatively higher incidence of undergoing laparotomy within $24 \mathrm{~h}$, and of diaphragmatic injury (Table 1). In addition, three of the stab wound patients were found at laparotomy to have gastric perforation, two of whom developed empyema (despite irrigation through the diaphragmatic defect). This may explain why the univariate analysis identified both stab wounds and diaphragmatic injury as risk factors for the development of empyema.

\section{DISCUSSION}

Tube thoracostomy is a common and vital tool in the immediate management of thoracic trauma; however, it is not without complications. Other than technical complications, empyema represents a major burden, which (assuming an approximately 5\% incidence and requiring thoracoscopy drainage) can represent as much as $\$ 118,000$ per 100 patients who receive a chest tube (1). However, some series have documented the incidence of empyema as high as $18 \%$ (3).

Empyema following trauma is characterized by a preponderance of Gram-positive organisms and early loculations, presumably due to hemothorax being present (2). Empyema in this setting occurs relatively early in the hospitalization, as opposed to trauma patients who develop empyema as a complication of ventilator-associated pneumonia (11). A number of risk factors have been identified, but there are conflicting data in the literature $(1,2,5,11-18)$. The routine use and duration of antibiotics that provide Gram-positive coverage has been vociferously debated $(1-4,6,12,13)$. Reviewing the available literature in 2000, the Eastern Association for the Surgery of Trauma noted that $24 \mathrm{~h}$ coverage appeared to be equivalent to longer periods, and the general consensus is that most surgeons believe that at least one dose is better than none (3).

One reason that there is a bias toward at least some antibiotic coverage is that the predominant etiology for empyema appears to be contamination of hemothorax during the actual tube placement, with a preponderance of $S$ aureus $(2,4,5,12,17,18)$. Retained hemothorax after tube thoracostomy has been reported to occur in approximately 5\% of cases, although, like empyema, rates as high as $18 \%$ have been reported depending on how it is defined and diagnosed $(5,10)$.

CT scan is clearly more accurate in defining residual intrathoracic volume following tube thoracostomy, and can, depending on institutional bias, change management in nearly one-third of patients who have residual pleural changes on plain radiograph $24 \mathrm{~h}$ after admission (7). Historically, there has been concern that any retained hemothorax can lead to complications of fibrothorax, thus prompting aggressive drainage. However, in the vast majority of cases clinically relevant fibrothorax is really a consequence of infection complicating the hemothorax. Furthermore, much of the experience prompting aggressive drainage for fear of fibrothorax was based on plain radiographic detection of hemothorax rather than the more sensitive CT imaging, and presumably reflected a larger volume of blood.
TABLE 2

Risk factors and correlation with empyema

\begin{tabular}{|c|c|c|c|}
\hline Risk factor & $\begin{array}{l}\text { Impact on } \\
\text { empyema }\end{array}$ & $\begin{array}{c}\text { Univariate } \\
\text { analysis, } \\
\text { P }\end{array}$ & $\begin{array}{c}\text { Multivariate } \\
\text { analysis, } \\
\text { P }\end{array}$ \\
\hline \multicolumn{4}{|l|}{ Injury severity score } \\
\hline With residual hemothorax & $31.4 \pm 26$ & 0.09 & 0.03 \\
\hline Without residual hemothorax & $22.6 \pm 13$ & & \\
\hline \multicolumn{4}{|c|}{ Systolic blood pressure on admission to the $\mathrm{ER}, \mathrm{mmHg}$} \\
\hline With residual hemothorax & $102.7 \pm 40$ & 0.1 & 0.88 \\
\hline Without residual hemothorax & $121 \pm 30$ & & \\
\hline \multicolumn{4}{|l|}{ Stab wound, n (\%) } \\
\hline With residual hemothorax & $5(33)$ & 0.006 & 0.16 \\
\hline Without residual hemothorax & $4(5)$ & & \\
\hline \multicolumn{4}{|l|}{ Left-sided hemothorax, n (\%) } \\
\hline With residual hemothorax & $7(15)$ & 0.05 & 0.25 \\
\hline Without residual hemothorax & $2(4)$ & & \\
\hline \multicolumn{4}{|l|}{ Diaphragmatic injury, n (\%) } \\
\hline With residual hemothorax & $4(36)$ & 0.005 & 0.1 \\
\hline Without residual hemothorax & $5(5)$ & & \\
\hline \multicolumn{4}{|c|}{ Residual fluid after one or more chest tubes, $\mathrm{n}(\%)$} \\
\hline With residual hemothorax & $7(33)$ & 0.001 & 0.001 \\
\hline Without residual hemothorax & $2(2)$ & & \\
\hline
\end{tabular}

If a residual hemothorax is identified, video thoracoscopic drainage, particularly if performed within two to three days, has been shown to result in lower complications and length of stay compared with placing more tubes, and appears to be more cost-effective than lytic therapy (19). In patients who cannot tolerate single lung ventilation for video thoracoscopic drainage, simple pleuroscopic approaches using 'rigid' thoracoscopy can still be performed (20).

Our results were consistent with the notion that placing a tube thoracostomy and not draining the effusion, such that fluid is still visible on plain radiograph after the patient leaves the acute management area, is associated with a marked increase in the risk of empyema, particularly in more severely injured patients. A CT scan can help confirm the residual fluid if there is difficulty distinguishing between pulmonary contusion and pleural fluid, but is not mandated. Consideration should be given to early thoracoscopic drainage and washout before loculations make the procedure more difficult, ideally within $24 \mathrm{~h}$ to $48 \mathrm{~h}$ after admission. Alternatively, close follow-up with CT or ultrasound may help direct earlier intervention. Patients with stab wounds that result in both gastric perforation and diaphragmatic injury may benefit from thoracoscopy to ensure complete pleural washout.

The data in the present study represent a concurrent study with small numbers. In addition, the different radiographic techniques may have resulted in hemothoraces not being detected. We did not design the study to evaluate whether retained hemothoraces detected by CT but not by plain CXR were associated with a different risk of empyema. Although our study supports the notion that once a chest tube is placed (and residual hemothorax is noted on plain CXR) patients are at an increased risk of empyema, it cannot be considered definitive. However, it does stress the importance of following these patients closely. A more large-scale prospective, multicentre 
study is needed to definitively determine whether routine CXR might serve to identify patients at increased risk of developing empyema after tube thoracostomy.

Presented at the 37th Annual Meeting of the Western Trauma Association, Steamboat Springs, Colorado, USA, March 1, 2007.

\section{REFERENCES}

1. Maxwell RA, Campbell DJ, Fabian TC, et al. Use of presumptive antibiotics following tube thoracostomy for traumatic hemopneumothorax in the prevention of empyema and pneumonia - A multi-center trial. J Trauma 2004;57:742-8.

2. Richardson JD, Carrillo E. Thoracic infection after trauma. Chest Surg Clin N Am 1997;7:401-27.

3. Luchette FA, Barrie PS, Oswanski MF, et al. Practice management guidelines for prophylactic antibiotic use in tube thoracostomy for traumatic hemopneumothorax: The EAST Practice Management Guidelines Work Group. Eastern Association for Trauma. J Trauma 2000;48:753-7.

4. LoCurto JJ Jr, Tischler CD, Swan KG, et al. Tube thoracostomy and trauma - antibiotics or not? J Trauma 1986;26:1067-72.

5. Helling TS, Gyles NR 3rd, Eisenstein CL, Soracco CA. Complications following blunt and penetrating injuries in 216 victims of chest trauma requiring tube thoracostomy. J Trauma 1989;29:1367-70.

6. Gonzalez RP, Holevar MR. Role of prophylactic antibiotics for tube thoracostomy in chest trauma. Am Surg 1998;64:617-20.

7. Velmahos GC, Demetriades D, Chan L, et al. Predicting the need for thoracoscopic evacuation of residual traumatic hemothorax: Chest radiograph is insufficient. J Trauma 1999;46:65-70.

8. Abboud PA, Kendall J. Emergency department ultrasound for hemothorax after blunt traumatic injury. J Emerg Med 2003;25:181-4.
9. Brooks A, Davies B, Smethhurst M, Connolly J. Emergency ultrasound in the acute assessment of haemothorax. Emerg Med J 2004;21:44-6.

10. Karmy-Jones R, Jurkovich GJ. Blunt chest trauma. Curr Probl Surg 2004; 41:211-380.

11. Watkins JA, Spain DA, Richardson JD, Polk HC Jr. Empyema and restrictive pleural processes after blunt trauma: an under-recognized cause of respiratory failure. Am Surg 2000;66:210-4.

12. Aguilar MM, Battistella FD, Owings JT, Su T. Posttraumatic empyema. Risk factor analysis. Arch Surg 1997;132:647-50.

13. Romanoff $H$. Prevention of infection in war chest injuries. Ann Surg 1975;182:144-9.

14. Spanjersberg WR, Ringburg AN, Bergs EA, Krijen P, Schipper IB. Prehospital chest tube thoracostomy: Effective treatment or additional trauma? J Trauma 2005;59:96-101. (Erratum in 2005;59:788-93).

15. Vassiliu P, Velmahos GC, Toutouzas KG. Timing, safety, and efficacy of thoracoscopic evacuation of undrained post-traumatic hemothorax. Am Surg 2001;67:1165-9.

16. Weissberg D, Refaely Y. Pleural empyema: 24-year experience. Ann Thorac Surg 1996;62:1026-9.

17. Eddy AC, Luna GK, Copass M. Empyema thoracis in patients undergoing emergent closed tube thoracostomy for thoracic trauma. Am J Surg 1989;157:494-7.

18. Hoth JJ, Burch PT, Bullock TK, Cheadle WG, Richardson JD. Pathogenesis of posttraumatic empyema: The impact of pneumonia on pleural space infections. Surg Infect (Larchmt) 2003;4:29-35.

19. Meyer DM, Jessen ME, Wait MA, Estrera AS. Early evacuation of traumatic retained hemothoraces using thoracoscopy: A prospective, randomized trial. Ann Thorac Surg 1997;64:1396-400.

20. Karmy-Jones R, Vallieres E, Kralovich K, et al. A comparison of rigid $-\mathrm{v}$ - video thoracoscopy in the management of chest trauma. Injury 1998;29:655-9. 


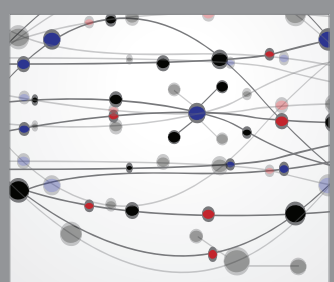

The Scientific World Journal
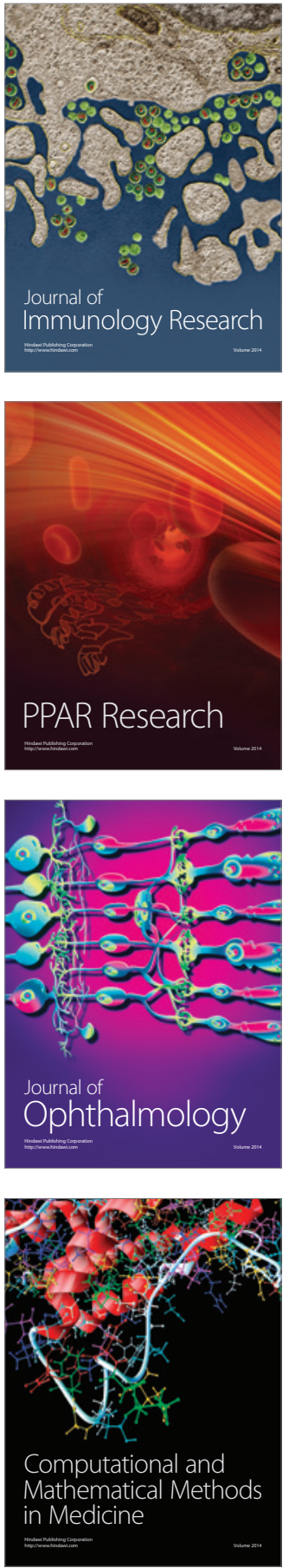

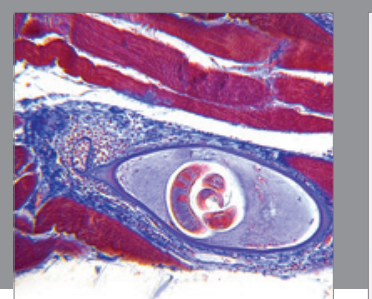

Gastroenterology Research and Practice

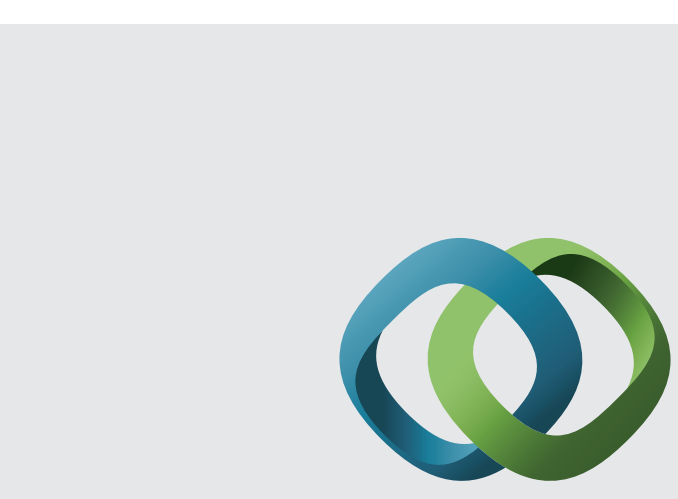

\section{Hindawi}

Submit your manuscripts at

http://www.hindawi.com
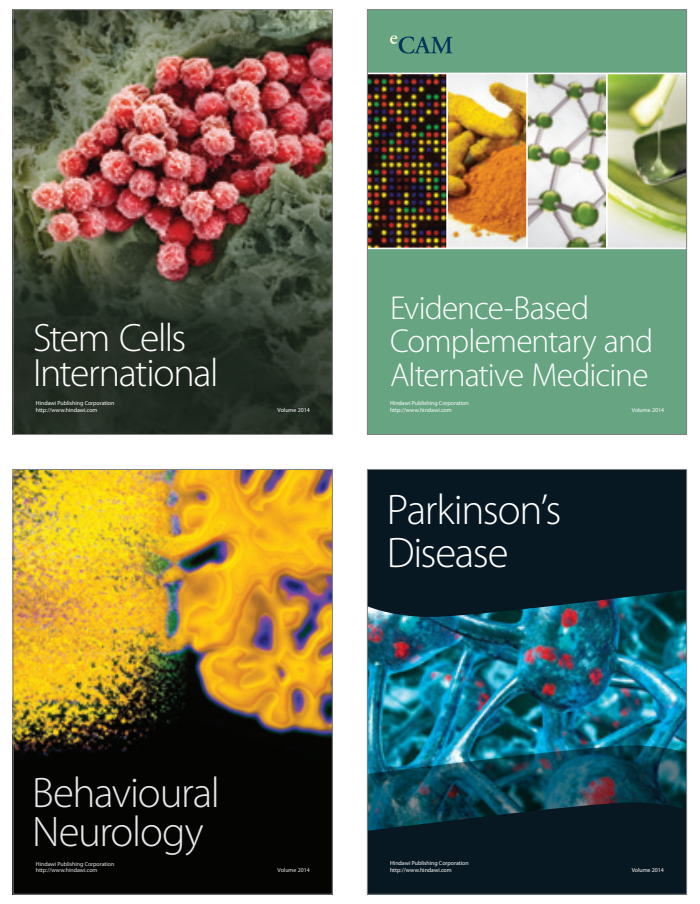
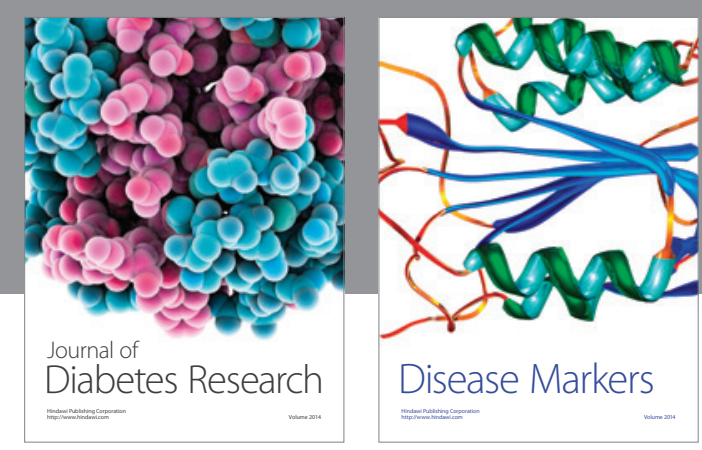

Disease Markers
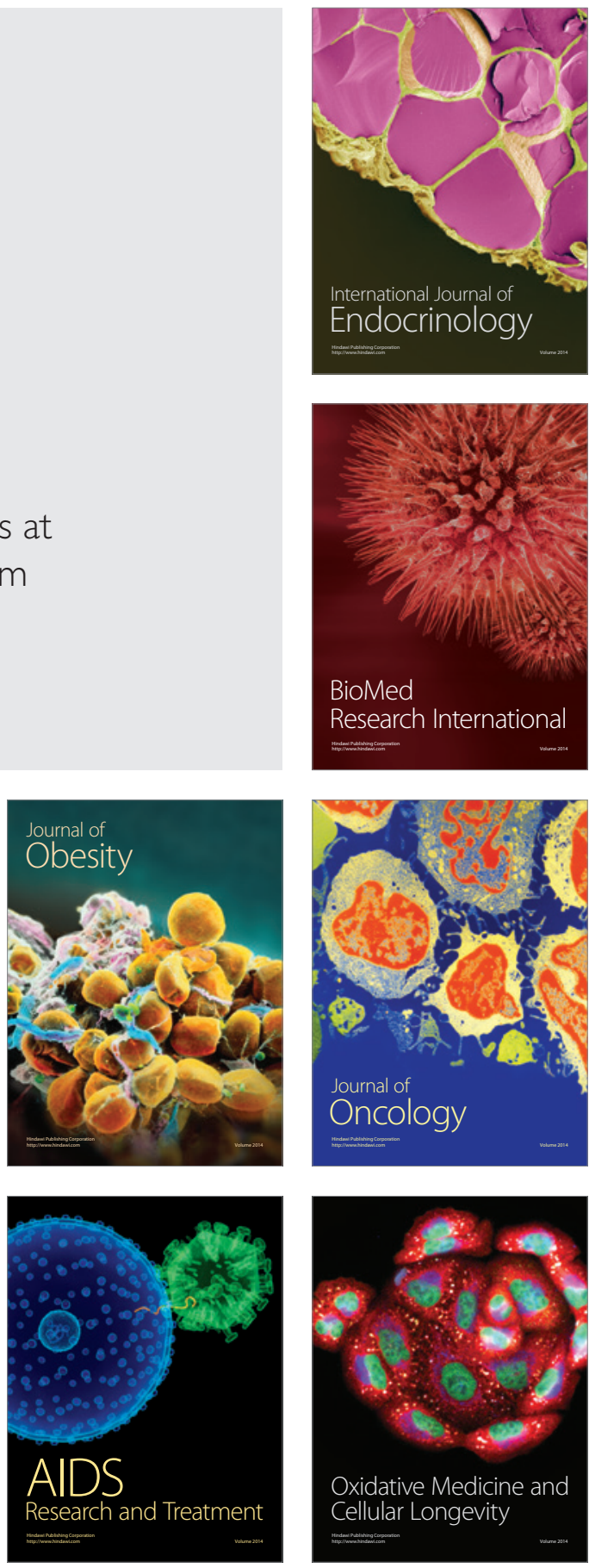